\title{
Does Heterogeneity Hinder Democracy?
}

\author{
Wolfgang Merkel ${ }^{\text {a) }}$ and Brigitte Weiffen ${ }^{\text {b) }}$ \\ a) Social Science Research Center Berlin (WZB), Research Unit "Democracy: \\ Structures, Performance, Challenges", Germany \\ wolfgang.merkel@wzb.eu \\ b) University of Konstanz, Department of Politics and Public Administration, Germany \\ brigitte.weiffen@uni-konstanz.de
}

\begin{abstract}
Research linking heterogeneity and democracy usually focuses on one single dimension of heterogeneity, such as the distribution of power resources, income inequality, gender inequality, or ethnic fractionalization. Empirical results have so far been inconsistent. This article attempts a sound conceptualization of the phenomenon of heterogeneity. In order to assess whether and how heterogeneity hampers democracy, we will first define what "heterogeneity" means and examine its various dimensions. Then we will discuss why and in which respect heterogeneity constitutes a challenge to democratic transition and consolidation and will review previous research. Our empirical analysis gauges the effect of various dimensions of heterogeneity on the political trajectory of states since the beginning of the third wave of democratization. We find that, while most facets of heterogeneity do not hinder democratic transition, most of them complicate democratic consolidation. Our final discussion offers some suggestions on how the obstacles that heterogeneity poses for democratic development could be overcome and which principles, procedures and institutions are most appropriate to deal with each of the different dimensions of heterogeneity.
\end{abstract}

\section{Keywords}

democratic transition, democratic consolidation, diversity, ethnic heterogeneity, inequality 


\section{Introduction}

Ever since Plato and Aristotle, it has been commonly held among political theorists that extreme inequalities in a society and a high amount of subcultures and cleavages are unfavorable for the development of democracy. Extreme differences among citizens in culture, status, income and wealth help to produce hegemonic and discriminatory regimes. If heterogeneity is politically transformed into severe polarization between antagonistic groups, democratic regimes run the risk to collapse or survive only as diminished subtypes of democracy.

Heterogeneity is perceived as a challenge to democracy both with respect to advanced welfare states and to developing or (post-)conflict states. On the one hand, heterogeneity potentially destabilizes mature democracies. On the other hand, heterogeneity often poses an obstacle for emerging democracies to consolidate. Here, different scenarios come to mind: countries where the indeterminacy of the transitional situation potentially leads to a recourse to and the polarization of primordial identities, post-conflict states where heterogeneity constituted an element (or cause) of enduring conflicts, or democratic countries facing strong socioeconomic inequalities and imbalances. Inclusion is usually cited as the political system's answer to heterogeneity (Lijphart 1999). However, we have to ask whether Western democracy, as we know it, still provides all the principles, institutions and actors which are needed to include the old and new diversity of its societies and citizens and whether newly emerging democracies are already equally equipped with those capacities of inclusion.

Up to now, research linking heterogeneity and democracy has usually focused on one single dimension of heterogeneity, such as the distribution of power resources, income and gender inequalities, or ethnic fractionalization. Empirical results have so far been inconsistent. From our point of view, therefore, a sound conceptualization of the phenomenon of heterogeneity is necessary. This article attempts to draw a cognitive map, which might be helpful to place all the single questions associated with heterogeneity and its impact on mature and emerging democracies within a more coherent frame. In order to assess whether heterogeneity hampers democracy, we will first define what "heterogeneity" means and examine its various dimensions. Then we will discuss why and in which respect heterogeneity constitutes a challenge to democracy and will review previous research on the link between various dimensions of heterogeneity and 
the development of democracy. The empirical analysis will gauge the effect of heterogeneity on the political trajectory of states since the beginning of the third wave of democratization and will for the first time account for various dimensions of heterogeneity. In our final discussion, we will offer some suggestions on how the obstacles that heterogeneity poses for democratic development could be overcome and which principles, procedures and institutions are most appropriate to deal with each of the different dimensions of heterogeneity.

\section{Defining and Mapping "Heterogeneity"}

Generally, the term "heterogeneity" denotes the condition of being composed of differing elements. In contrast to "diversity" which refers to the inclusion of different types of people (for instance, people of different sex, race or culture) in a group or organization, the concept of heterogeneity is broader. Heterogeneity describes the socio-cultural complexity and differentiation of social structures in modern societies (Hillmann 1994: 331332; Reinhold, Lamnek \& Recker 2000: 260). However, the uses of the term or of the concept of heterogeneity are neither uniform, nor are the differences or similarities of the related terms obvious. Before the term became fashionable in social science and philosophy its contents were termed sub-cultural division or plurality. The relation to cleavage concepts is also not completely clear. We will argue that heterogeneity of societies becomes particularly relevant when it is politicized, mobilized, and organized. Politicization, mobilization, and organization are the mechanisms which transform heterogeneity into cleavages. Therefore cleavages can, but do not necessarily have to be, the structural consequences of heterogeneous societies. This means that we have to distinguish between heterogeneity as the realm of descriptive socio-structural identities and as politically mobilized groups. Expressed in Marxian terms, we can speak about a social entity "in itself" and "for itself". Social classes or socio-cultural identities only become a potential challenge to political order in general, and democracy in particular, if they become self-conscious groups and become able to act politically for their own good. ${ }^{1}$

\footnotetext{
1) This, however, does not preclude the possibility that marginalized groups without selfconsciousness, say paupers or welfare recipients, can constitute a challenge for the quality
} 
The analysis of heterogeneity links the micro and the macro level in social analysis. Heterogeneity is logically linked to identity. Only if clearly discernible identities exist in society can we also speak of heterogeneity, which reflects the social universe of these different identities. People tend to describe their identities in distinguishing themselves from others, and they do it in modern societies in increasingly multiple ways: class, gender, ethnicity, race, language, religion, sexual orientation and so forth. These identities are by no means mutually exclusive, they rather coexist in different combinations and forms in complex societies and nation-states. Although people may define themselves predominantly as workers, women or Muslims, these self-identifications tend to overlap and cumulate. On the societal level, therefore, heterogeneity is the aggregate of individual affiliations. The concept of heterogeneity is hence particularly interesting for democratization research as it could constitute a junction between structure and agency approaches. Cultural and socio-structural reflections on the impact of heterogeneity on democracy could then function as an interface which lays open both the contributions of economic, cultural and structural conditions on the macro level and the importance of actors' preferences, rational calculations and decisions on the micro and meso levels.

To put some order into the enumeration of dimensions of heterogeneity in complex societies, one can follow Claus Offe and group them into three types of cleavages: interest-based, identity-based, and ideology-based cleavages (cf. Offe 2003: 157ff):

- Interest-based cleavages are related to the control over, and the distribution of, resources, and are typical for class conflicts. The common wisdom considers these distributional conflicts as the easiest to resolve if they are not nested in ideological conflicts. If the conflict can be institutionalized by a fair tax-and-welfare state supported by an economic positive-sum game, the distributional conflict over resources can be peacefully processed within the constitutional frame of liberal or social democracies.

of democracy. In these cases, the groups are not a threat because of their potential political actions, but rather because of their actual non-actions, namely their exclusion from the social and political process - a phenomenon aptly termed "low intensity citizenship" by O’Donnell (1993, 1998). Low intensity citizenship rarely challenges the existence of democracy as such, but poses severe limits to the quality of democracy. 
- Ideology-based cleavages relate to comprehensive doctrines which spell out proper and desirable values, rights, and duties. The comprehensive ideological doctrines often prevent the adherents of different ideologies to agree on common procedures and institutions to negotiate their conflicts over rights and duties. These conflicts are exemplified by Marxist doctrines in the past and by fundamentalist religious views at present and are typically more difficult to resolve.

- Identity-based cleavages are related to ethnic identity. There are two distinct ways in which the term "ethnic" is interpreted. In the narrower construal of the term, "ethnic" groups mean racial or linguistic groups. This is the sense in which the term is widely understood in popular discourse. According to a second, broader definition which is increasingly becoming the standard meaning in the social sciences, all conflicts based on ascriptive group identities - race, language, religion, ${ }^{2}$ tribe, or caste - can be called ethnic (Horowitz 1985: 41-54; Varshney 2001: 364). Typical demands in these conflicts are recognition and consequently specific group rights for minorities, or different models of power sharing (cf. Horowitz 2008; Lijphart 1991, 2004). The majority within a political community can respond by granting these rights, but often prefers assimilation or integration of the diverse individuals into a nation or political community with a civic national identity, based not on the co-existence of ethnic groups but on the civic rights and duties of individuals. Here, mainstream sociologists and political scientists argue that identities and recognition are delicate issues to negotiate and therefore conflicts of identity are the most difficult to resolve and threaten to end up in intransigent battles.

The three types of heterogeneity are theoretically distinct types. In reality, they often overlap, cumulate or cross-cut through different identities. Class conflicts can also be ideologically polarized if economic growth is absent and/or the lower classes challenge the fairness of the fundamental distributional rules. Ideological conflicts and identity-based conflicts are not only about rights and recognition, but also tend to be about resources and their distribution. Such a cumulative overlap may make these conflicts even

\footnotetext{
2) Although religion is often subsumed as an ascriptive element under the broad meaning of ethnic identity, it is in fact not ascriptive, because adult people can choose, reject, and change their religious beliefs by their own will.
} 
more difficult to resolve than an ideal-typical fight over ideology or identity, since sometimes the champions of economic interests fuel recognition conflicts by willfully masking rational choice-driven resource seeking as an outbreak of deep-rooted ethnic antagonisms.

In the 1950s and 1960s modernization theory from Parsons (1964, 1971) to Lipset (1959) and Lerner (1958), Bell (2000) and (the early) Huntington $(1968,1971)$ predicted the decline, if not the disappearance, of these traits of traditional societies. According to them, the primordial and ascriptive racial, ethnic and religious cleavages would be weakened and their related identities would be embedded in a modern society and a secular political system based on universal, liberal values. The dominant conflict of modern societies would be over the distribution of economic resources. Even this distributional struggle would be institutionally tamed by social rights (Marshall 1992) in the coming post-ideological age (Bell 2000).

Five decades after these seminal predictions of modernization theory, we have to realize that they turned out to be utterly wrong. This is true not only for advanced post-industrial societies, but also on a global scale. All three types of cleavages and the respective conflicts are back in present modern societies and are challenging the stability and quality of democracy in- and outside the OECD world:

- Class conflict seems to have returned after three decades of neoliberal policies and the redistribution of wealth from the bottom up. In most countries that underwent political transformation since the 1980s, democracy did not yet deliver: Socioeconomic inequality remained high or even increased. The same happened in established democracies where, additionally, the once powerful organizations of the working class (trade unions and strong working-class parties) have dramatically lost the ability to effectively represent the collective interests of the workers and lower strata. This is the reason, Colin Crouch (2004) argues rather strongly, why most OECD democracies are entering the stage of postdemocracy.

- Ideology has had a resurgence back into modern societies: This is true for the political role of religion, as exemplified by the strong presence of Christian values in the US society and the re-fundamentalization of its evangelical denominations, and the migration of Muslim communities 
into the secular or Christian societies of Europe. Additionally, after the end of the Cold War Samuel Huntington foretold a "clash of civilizations" whose boundaries were mainly defined in religious terms (Huntington 1993). This thesis, inspired by the rise of political Islam since the Iranian revolution, is increasingly received and endorsed by public opinion since the upsurge of global Islamic terrorism. Right-wing populism might be another imprint of the ideology-based cleavage. As a reaction to enduring poverty and socioeconomic inequality in the developing world and conflictive North-South relations, among other factors, leftist ideology has also re-entered the stage in the shape of "socialism of the 21st century" promoted by Venezuelan President Hugo Chávez and his allies in Latin America.

- Since the 1970s, European nation-states have witnessed a growing revival of primordial ethnic identities, from Denmark to Spain and France to the Balkans. The concessions of different types of additional rights, such as group rights or devolution, did not lead to a moderation of the conflict potential, but rather seems to have intensified it. Tensions and conflicts erupted in Eastern Europe and the former Soviet Union when the demise of communism and hegemonic control led those countries' peoples to a rediscovery of their ethnic identities. Many of the recent severe internal conflicts and humanitarian crises around the world, as in Bosnia, Rwanda, Kosovo, East Timor, the Democratic Republic of Congo and Darfur, Sudan, to mention just some of the most prominent examples, exhibit an ethnic component.

There is no agreed-upon explanation as to why these three types of heterogeneity conflicts were not resolved, but rather have intensified during the last three decades. The reappearance of class conflict and the renaissance of the class society in Europe and beyond are fundamentally due to the accelerated unequal distribution of socioeconomic resources triggered by globalization, the dominance of neo-liberalism and the dismantling of the regulatory state. The religious issue resurfaced in Europe mainly because the Christian and secular majorities and their governments are reluctant to grant immigrant Muslim minorities the same rights, privileges, and recognition that the Christian majority enjoys. Whether it is actually true or not, the governments, and even more so, large parts of the society attribute their reluctance to recognize certain cultural traditions to their supposed or actual 
non-compliance with the basic constitutional rights, such as the equality of men and women. In contrast to the religious issue, most European governments were willing to fulfill the demands for equal and additional rights by the autochthonous ethnic minorities. If these minorities were well organized, disposed of considerable resources or of (violent) blackmail potential, the central governments also accepted territorial devolution.

It is interesting to note that while the three aforementioned types of heterogeneity were aggravated during the last three decades in many states and societies, one long-standing inequality was tamed at least in Western democracies: the legal, political and economic discrimination against women. Although the full socioeconomic equality of men and women has not yet been reached, the legal rights accorded to men and women are equal, the political representation and participation of women have improved and even the socioeconomic inequalities between men and women have decreased. Since equality between men and women was not normatively disputed by the relevant actors, it was easier to foster the implementation of equal rights and opportunities, sometimes by quotas or affirmative action. Compared to the 1950s and 1960s, men and women are now de jure and de facto recognized as "equal". This is one important argument against Colin Crouch's empirically problematic concept of post-democracy and against the chorus of those who diagnose and foresee a continuous decline of democratic quality.

\section{Why is Heterogeneity a Challenge to Democracy?}

Why does the reappearance (if they ever disappeared) of the various dimensions of heterogeneity pose challenges to democracy and which preconditions, spheres and institutions of democracy do they put under stress in particular? In the following, we will review hypotheses and empirical results that are advanced in the literature, taking into consideration both the effect of heterogeneity on (established) democracies and its impact on processes of democratization. The argument that coherent and homogeneous political communities are a pre-condition for a stable democracy is not new and found eminent proponents in political theory. If we do not want to begin with Plato and Aristotle in ancient Greek philosophy where heterogeneity of the demos and a good political order were anathema, then 
the liberal philosopher John Stuart Mill is certainly one of the most prominent sources for a principal skepticism that heterogeneous societies are compatible with democracy. In the 16th chapter of his Considerations on Representative Government, first published in 1861, Mill wrote:

Free institutions are next to impossible in a country made up of different nationalities. Among a people without fellow-feeling, especially if they read and speak different languages, the united public opinion, necessary to the working of representative government cannot exist. (Mill 1861: 289)

Mill's argument from the second half of the 19th century is not an ethnonationalist, but a democratic one. It can be similarly found in theories of deliberative democracy such as Jürgen Habermas' "The Structural Transformation of the Public Sphere" (1989/1962) or Bob Putnam's work on social capital and social trust (Putnam 1993, 1995) at the end of the 20th century. They argue that liberal democracies are only working if a lively public discourse takes place and there is sufficient social trust among fellow citizens. Pluralist nationalism based on primordial identity within a political community (Easton 1965) hinders or even destroys the preconditions for a democratic public discourse. The reasons can be found in the dynamic of the revival of nationalism, since, and here again we quote J.S. Mill (1861: 296):

each [nationalism] cultivates with party obstinacy its distinctive peculiarities; obsolete customs, and even declining languages, are revived to deepen the separation; each deems itself tyrannized over if any authority is exercised within itself by functionaries of a rival race.

Mill's second argument refers to the dynamic of aggravating cultural differences by strengthening the diversity of ethnic identities until they take on the disruptive character of a zero-sum game. It also can be interpreted as a "policy warning" to grant too many special group rights to particular nationalist communities within a free and democratic political system.

J.S. Mill is not alone. More than 100 years later, Robert Dahl (1971, 1989) developed similar thoughts. However, Dahl's terminology is different. He does not speak about nationalities, but about identities, subcultural divisions and pluralism when he writes: 
It is reasonable to suppose, then, that the prospects for polyarchy are greatly reduced if the fundamental beliefs and identities among the people of a country produce political conflicts and are correspondingly increased if beliefs and identities are compatible and therefore not a source of conflict. Thus as the strength and distinctiveness of a country's subcultures increase, the chances for polyarchy should decline. (Dahl 1989: 255)

Subcultures, according to Dahl's analysis, are typically formed around ethnic, religious, racial, linguistic, or regional differences and shared historical experiences or ancestral myths. Although Dahl unequivocally postulates that polyarchy is "significantly less frequent in countries with marked subcultural pluralism", he also argues that "cultural homogeneity is... not strictly necessary to polyarchy” (Dahl 1989: 255). Dahl's thinking resembles the basic ideas of Mill, but he is less apodictic in his conclusion than the liberal philosopher and gave the first hints that there are ways out of this dilemma. Numerous other scholars in sociology and political science, such as David Easton, Dankwart Rustow, Arend Lijphart and Claus Offe, subscribe to the basic reasoning that ethnic, linguistic, religious, and other identity conflicts make democratic governing more difficult.

While most of the theoretical debate revolves around the effect of heterogeneity on the stability of democracy, some studies also reflect on the prospects of heterogeneous societies for democratization. Some observers believe that, by fostering conflict, ethnic heterogeneity hinders democratization (Dahl 1971; Rabushka \& Shepsle 1972). However, empirical analyses on the impact of ethnic heterogeneity (no matter whether on conflict-proneness, on democratization or on democratic consolidation) are difficult to conduct, as cleavages between various types of identities could coincide, but also overlap. The probability that identity-based heterogeneity leads to conflict varies not only with the degree of fractionalization and the number of relevant cleavages, but also with the size of the groups, the amount of territorial segmentation, and the power distribution between the groups (Horowitz 1985). This is why the linear assumption that the more fractionalization, the higher the probability of a conflict, is questionable. The existence of a single majority group, i.e. a constellation where the largest group constitutes between 45 and 90 per cent of the population, is considered particularly problematic. The dominant majority tends to oppress the minority, and a government by the majority, even if democratically elected, is not necessarily accepted as legitimate by the 
minority. In turn, the effects of a constellation with two groups of approximately the same size are contested: While some scholars hold that such a relative equilibrium is conducive to consociational arrangements (Lijphart 1991; Schneckener 2002), others associate this constellation with the danger of polarization (Dahl 1971; Horowitz 1985; Montalvo \& ReynalQuerol 2005). The latter argue that a middle range of heterogeneity poses the highest risk, while there is a lower risk of conflict in both highly homogeneous and highly heterogeneous countries. In highly fragmented societies, groups are more inclined to build coalitions than to confront each other, and there is also a higher likelihood of cross-cutting cleavages.

Up to now, there have only been a few large- $\mathrm{N}$ empirical studies assessing the impact of racial, linguistic or religious heterogeneity on the development of democracy. Some studies, looking at the level or stability of democracy as dependent variable, found no significant effect of ethnic heterogeneity on the political regime (Fish \& Brooks 2004; Lane \& Ersson 2002), while others detected a negative effect (Clague, Gleason \& Knack 2001; Lane \& Ersson 2003). When analyzing democratization, Przeworski and his coauthors (Przeworski et al. 2000) as well as Teorell and Hadenius (2007) showed that fractionalization impedes democratization and tends to trigger democratic breakdown.

With respect to interest-based cleavages, sociological theories of modernization and social stratification suggested that the transition from the agrarian to the industrial society contributed to more social equality in the long run which in turn created favorable conditions for the development of democracy (Lenski 1966; Lenski, Nolan \& Lenski 1995). Only a society where relatively few people live in poverty offers the requisites for equal political participation (Dahl 2006; Lipset 1959). Hence, in addition to the level of economic development of a country, the distribution of material resources is regarded as important for the prospects of democracy. This assumption motivated many scholars to a closer empirical examination of the political consequences of social equality or inequality (Acemoglu \& Robinson 2006; Boix 2003; Bollen \& Jackman 1985, 1995; Burkhart 1997, 2007; Houle 2009; Meyer 2005; Muller 1988, 1995; Vanhanen $1997,2003)$. Although not all of these studies render statistically significant results, the main thrust is clear: the higher the inequality, the more problematic the sustainable consolidation of democracy.

According to Dahl (1971: chapter 6), a highly unequal distribution of key values such as income, wealth, status, education and knowledge are 
equivalent to inequality in the distribution of key political resources and hence unfavorable to competitive politics. Przeworski and his coauthors (1996: 43) have argued that "people expect democracy to reduce income inequality". Hence, democracy will only remain stable if it is not facing too high inequalities over a longer period of time, while "democracies with especially severe income inequalities are unstable" (Karl 2000: 154). In line with this assumption, many studies tried to link economic equality to the level of democracy and democratic stability. Using various indicators for the dispersion of power resources such as capital and land ownership, several analyses showed that greater equality results in a higher level of democracy (Midlarsky \& Midlarsky 1997; Vanhanen 1997, 2003).

The bulk of studies, however, analyze the association between inequality and democratic transitions or breakdowns. Looking at the time period between 1965 and 1980, Muller (1995) found that income inequality explains decline in democracy, particularly in countries on an intermediate level of economic development. If the situation of the poorest sectors of society does not improve even in spite of rising levels of socioeconomic development, a democratic breakdown becomes more likely (Reenock, Bernhard \& Sobek 2007). Houle (2009) also showed that more egalitarian democracies are much more likely to survive, while democracies with high inequality are far more likely to collapse. Przeworski and his coauthors (2000: 122) demonstrate that both dictatorships and democracies are less stable when characterized by high economic inequality. ${ }^{3}$ Other quantitative analyses, however, did not register an unequivocal negative effect of income inequality on democratic development (Bollen \& Jackman 1985).

Recently, an economic approach to democratization (Acemoglu \& Robinson 2006; Boix 2003) has conceptualized democratic transitions as distributional conflicts. Commonly, these approaches model two actors, the rich elite and the poor masses, and draw on the theory of income distribution which points out that economic growth initially leads to an increase in economic inequality (Kuznets 1955). As an immediate consequence, claims for redistribution are often raised by the disadvantaged sectors of the population. However, the authors differ with respect to the anticipated elite reaction to social unrest: According to Boix (2003), the

3) In turn, a dictatorship that attains high economic growth rates and, at the same time, undertakes measures to limit income inequality has good chances for survival (Feng 2003: 107). 
wealthy sectors feel threatened by popular claims and tend to protect their acquired possessions and vested rights by increasing repression. Only if, in the long run, the poor become better off thanks to a general increase in wealth, the fear of the ruling class of redistribution claims diminishes and they are hence more willing to agree to participation rights for the poorer sectors of the population.

In contrast to Boix who assumes that highly unequal authoritarian countries are less likely to transition to democracy, Acemoglu and Robinson (2006) stress that a dynamics of increasing inequality in autocracies can potentially lead to democratic transitions. Looking at democratizations in Western Europe at the turn of the twentieth century, they identify increasing inequality, a dwindling acceptance of exclusionary structures, a revolutionary inclination of the masses and the resulting threat to the elites as the steps toward an expansion of the right to vote. To prevent the emerging protests from escalating into violent conflict, authoritarian leaders concede more participation to the citizens. The transition to democracy "shifts future political power away from the elites to the citizens, thereby creating a credible commitment to future pro-majority policies" (Acemoglu \& Robinson 2006: 26, emph. in original). Acemoglu and Robinson assume that the relationship between inequality and the probability of democratization follows an inverted U-shaped curve: In autocracies characterized by relative equality, there is no revolutionary pressure from the masses. In the face of an intermediate level of inequality, they argue, it is a rational decision of the elites to concede more participation rights to broader sectors of the population in order to prevent revolutionary upheavals since the masses can rely on increased economic and cognitive resources to exert pressure on those who rule. In turn, if disparities are too large, the elites have so much to lose that their rational calculations lead them to respond to mass protests by repressive means, and the masses in turn cannot rely their protest on reasonable economic, cognitive and organizational resources.

The debate between Boix (2003) and Acemoglu and Robinson (2006) remains unresolved. Notwithstanding their seemingly contradictory findings, these game-theoretic perspectives exemplify why the question of heterogeneity has the potential to connect structural and agency approaches in democratization studies: Both studies model rational, egoistic behavior of actors on the micro level but, at the same time, make predictions about the consequences of that behavior on the macro level. They also illustrate an argument that is relevant for all forms of heterogeneity: The ideal types 
of heterogeneity introduced above constitute a challenge to democracy especially when they become politicized and manifest themselves in political cleavages. With respect to ethnic heterogeneity, Kreuzer and Weiberg (2007) have argued that basically, ethnic groups are neutral categories that individuals belong to by birth. To turn ethnic groups into a social or political category, a central factor called "ethnicity" or "ethnic consciousness" is necessary, implying that the fact of belonging to a certain ethnic group turns into cultural identity and finally into political identity. Drawing a direct parallel between identity-based and interest-based cleavages, Brass (1991: 19) states that "Ethnicity is to ethnic category what class consciousness is to class." In the same vein, Tilly $(2000,2007)$ stated that a democracy can survive in the face of large inequalities, as long as political rights and duties are not allocated along cleavages separating diverse groups. Only if it takes the shape of politicized cleavages, heterogeneity potentially undermines the coherence of political communities. The importance of politicization dynamics points us once again to the link between structures, actors, and collective action mentioned above: Conflicts do not automatically erupt once certain structural conditions, such as a certain degree of heterogeneity are given, but they are planned and organized by political actors.

But even if we agree that heterogeneity by itself is not a sufficient reason for making democracy impossible, we should strive for more evidence on the link between heterogeneity and democracy, namely to what extent and under what conditions cleavage-based conflict can be handled by a democracy, and which types of heterogeneity and conflict may be particularly deleterious for democratic transitions and established democracies.

Departing from the findings outlined above, our hypotheses regarding the effect of heterogeneity on democratic stability and democratic transitions are as follows: We assume that severe identity-based cleavages, especially those that erupted into violent conflict, foster political instability and may hence prompt both democratic transition and breakdown. Consequentially, they tend to hinder democratic consolidation. With respect to interest-based cleavages, there is up to now a mixed picture concerning their effect on democratic transition: A high amount of socioeconomic inequality might foster, but might also hinder democratization. In turn, we expect that high inequality will impede democratic consolidation. 
With respect to the third type mentioned in section 2, ideology-based cleavages, we found that there is hardly any research on the impact of that type of cleavages on democracy. In fact, there are two good reasons for that: First, most variants of ideology-based cleavages derive from one of the other types of cleavages, which makes it close to impossible to find indicators capturing ideology-based cleavages only. Class conflicts often result from socioeconomic inequalities and are hence operationalized by income distribution or other indices of power dispersion. Ideological cleavages resulting from fundamentalist religious currents are in empirical research often operationalized as religious fractionalization or the dominance of a religion or religious doctrines allegedly harmful for democracy. ${ }^{4}$ Second, many potential operationalizations of ideological cleavages overlap with the dependent variable. A regime characterized by communist or religious fundamentalist ideology, for instance, is by definition incompatible with the Western concept of liberal democracy. Although we find the theoretical distinction between three types of cleavages useful in principle, our empirical analysis will be restricted to the identity-based and interestbased cleavages which are clearly separable both from each other and from the dependent variable.

As we intend to look not only at established democracies, but also at processes of democratization in non-Western societies, we decided to control for gender inequality. Gender equality may be conducive to democracy by promoting a less hierarchical cultural milieu for decisionmaking (Inglehart, Norris \& Welzel 2002; Paxton 2009). Although, as argued above, inequality between the sexes has been greatly reduced in Western societies, it may still pose an obstacle to democratization in the developing world.

\section{Empirical Evidence}

When assessing the impact of any potential influential factor on democracy, it is important to clearly spell out the exact concept (Adcock \& Collier 2001) of democracy that is used. It makes a difference whether the dependent variable in focus is the level of democracy or whether the focus

\footnotetext{
4) The recent debate mainly focuses on Islam as an impediment to democracy (Donno \& Russett 2004; Fish 2002; Stepan \& Robertson 2003; Weiffen 2004).
} 
is on processes of change, such as transitions to democracy, democratic breakdowns, or the stability of democracy over time (cf. Weiffen 2009: 62). In fact, Houle (2009) criticizes the previous literature on the relationship between inequality and democracy because of its failure to distinguish between democratization (i.e. transition to democracy) and consolidation (i.e. no democratic breakdown).

To study the dynamics of the influence of heterogeneity on democratization, it does not make much sense to look only at levels of democracy at a given point in time. However, the dimensions of heterogeneity under scrutiny here are rather stable from year to year and even from decade to decade, and for most of the indicators, annual data are not available. Hence, it is not possible to discern any effects of changes in heterogeneity on democratic development. Nevertheless, the measures of heterogeneity can be regarded as predictors of success or failure. Even without annual data, we can still assess how a certain type and amount of heterogeneity impacted on a country's probability to democratize, and whether a country, once it crossed the threshold to electoral democracy, achieved the goal of full democracy given a certain degree of heterogeneity. Hence, our aim is to look at the influence of heterogeneity on success or failure of democratization during the third wave.

Therefore, we choose a special operationalization of the dependent variable to account for the success or failure of democratization in the time period from 1975 to 2007. It captures both the question whether a country underwent a democratic transition and whether democracy subsequently consolidated or not. In a first step, our operationalization differentiates between states that registered a change in regime type during the third wave of democracy and those that did not; in a second step, it rates the success (or failure) of regime change. Following Fish and Wittenberg (2009) and drawing on the Freedom House Index (FHI), ${ }^{5}$ we sort countries into five categories. Two categories - "established democracies" and "established autocracies" - contain countries that have not experienced any regime change since 1975. Established democracies exhibit a FHI of 2.5 or better each year since 1975 . Established autocracies lie on the other

\footnotetext{
5) Freedom House rates countries on a 7 -point scale for both political rights and civil liberties, 1 representing the most free and 7 the least free. The FHI we refer to in the text is the mean of both scales. The full dataset and information on the methodology are available on the organization's website: http://www.freedomhouse.org.
} 
end of the spectrum: Their annual FHI was never better than 4 . The other three categories consist of three different kinds of democratizers (i.e. countries that had a score of 3.5 or better in at least one year during the period 1975-2007): "Robust democratizers" are the successful cases that failed to reach the 2.5 level in one or more years between 1975 and 2004, but subsequently attained that level (or better) in all three consecutive years from 2005 to 2007. The "tenuous democratizers" are countries that at least in one yearly survey scored 3.5 or better, failed to score as full democracy but have also avoided autocracy in the recent past, meaning that their FHI between 2005 and 2007 averages better than 4 but worse than 2.5. The "failed democratizers" have an experience of political opening, but subsequently underwent a major reversal. They scored a 3.5 or better in at least one year since 1975, but between 2005 and 2007 have averaged 4 or worse. ${ }^{6}$

In order to unearth the dimensions of heterogeneity that hamper democracy, we use statistical analyses that treat the five categories of countries as the dependent variable. We examine the influence of heterogeneity by employing multiple comparisons and ordered probit regression models. Multiple comparisons are used in the context of analysis of variance (ANOVA) to check whether there are differences in population means among more than two populations (in our case, the five regime categories). With the help of post-hoc comparison tests, it can be determined which groups significantly differ from others in respect of the mean.

The dimensions of heterogeneity we include are socioeconomic inequality, ethnic heterogeneity, and gender inequality. Given that we argued that heterogeneity is most likely to affect democracy once it becomes politicized, the empirical investigation should ideally include the actor perspective. However, the review of the literature in section 3 has shown that even the most recent studies in the field, despite specifying models on the actor level, resort to structural data when it comes to empirical analyses and do not even address this divergence between micro and macro level as a problem (Acemoglu \& Robinson 2006; Boix 2003; Houle 2009). This might be attributable to the fact that in the field of heterogeneity, structure and

\footnotetext{
6) Four cases which Fish and Wittenberg categorize as "tenuous democratizers" end up in the "failed democracies" category according to our calculations, even when exactly following the coding rules specified by Fish and Wittenberg (2009: $250 \mathrm{f}$ ): Guinea-Bissau, Morocco, Malaysia, and Thailand. All of them averaged 4 or worse in the 2005-2007 period.
} 
agency approaches are closely linked both in theoretical reasoning and empirical measurement: Indicators of heterogeneity, even if aggregated on the national level, measure the distribution of certain characteristics, affiliations and (access to) resources among individuals. Even if it is impossible to capture actors' motivations and goals with this data, they do enable us to gauge the salience of the heterogeneity issue (and potential conflicts arising from it) within a society.

We measure gender inequality using the gender literacy gap, which is the male literacy rate minus the female literacy rate, so that a higher number is a sign of greater inequality between sexes. ${ }^{7}$ To account for socioeconomic heterogeneity, we draw on a range of indicators, such as the Gini Index as the most common indicator of income inequality ${ }^{8}$ and several variables from Vanhanen's 2007 updated index of power resources (Vanhanen 2009a, b): tertiary enrollment ratio and adult literacy rate as indicators for the access to knowledge and education; and percentage of family farms, percentage of agricultural population, degree of decentralization of economic power resources and a combined index of economic power resources as indicators for the distribution of key economic resources. ${ }^{9}$

7) Data was taken from UNDP (2002).

8) Data was taken from the World Development Indicators Online Database (2010), available at http://data.worldbank.org/data-catalog. To minimize missing values, means over the years 1998-2007 were calculated (in fact, for many countries, data is available for just one of those years). In some cases where no information was available for those years, we included data from the mid-1990s or 2008.

9) Tertiary enrollment ratio is based on the percentage of students enrolled in universities and institutes of higher learning within the relevant age group. Adult literacy rate is calculated as a percentage of adult population. Family farms means (FF) the percentage of total cultivated area or of total area of holdings. Agricultural population (AP) measures the proportion of agricultural population between 2000 and 2005. Estimated degree of decentralization of economic power resources (DD) is calculated by adding the percentage of the population living under the poverty line with the richest 10 percent of the population, calculating the proportion of their income or expenditure compared to the whole population minus 10 percentage units, and then subtracting the sum from 100. Index of Economic Power Resources is calculated by the formula $E R=\left(\mathrm{FF}^{*} \mathrm{AP}\right)+\left(\mathrm{DD}^{*} \mathrm{NAP}\right)$, where $\mathrm{NAP}=100-\mathrm{AP}$ (cf. Vanhanen 2009a). Admittedly, one could harbor doubts whether some of Vanhanen's single indicators really reflect inequality or might not as well be interpreted as measures of socioeconomic development level. The same holds true for the gender literacy gap. 


\section{Table 1}

Comparison of means: Economic power resource distribution

\begin{tabular}{|c|c|c|c|c|c|}
\hline & & \multirow[b]{2}{*}{$\begin{array}{l}\text { Gini } \\
\text { Index }\end{array}$} & \multicolumn{3}{|c|}{ Economic power resources } \\
\hline & & & $\begin{array}{c}\text { Family } \\
\text { farms (\%) }\end{array}$ & $\begin{array}{l}\text { Agricultural } \\
\text { population } \\
(\%)\end{array}$ & $\begin{array}{c}\text { Degree of } \\
\text { decentralization }\end{array}$ \\
\hline \multirow[t]{2}{*}{ Established autocracy } & mean & 40.92 & 42.00 & 48.04 & 29.70 \\
\hline & $\mathrm{N}$ & 29 & 47 & 47 & 47 \\
\hline \multirow[t]{2}{*}{ Failed democratizer } & mean & 40.05 & 46.04 & 50.96 & 33.56 \\
\hline & $\mathrm{N}$ & 23 & 25 & 25 & 25 \\
\hline \multirow[t]{2}{*}{ Tenuous democratizer } & mean & 45.95 & 47.93 & 51.97 & 33.47 \\
\hline & $\mathrm{N}$ & 29 & 30 & 30 & 30 \\
\hline \multirow[t]{2}{*}{ Robust democratizer } & mean & 41.56 & 49.13 & 24.18 & 54.13 \\
\hline & $\mathrm{N}$ & 38 & 40 & 40 & 40 \\
\hline \multirow[t]{2}{*}{ Established democracy } & mean & 34.33 & 61.66 & 7.72 & 71.28 \\
\hline & $\mathrm{N}$ & 25 & 29 & 29 & 29 \\
\hline
\end{tabular}

Oneway ANOVA reveals that there are statistically significant differences between the groups [Gini Index: $\mathrm{F}(143)=5.945, \mathrm{p}<0.001$; Family farms: $\mathrm{F}(170)=4.378, \mathrm{p} \leq 0.002$; Agricultural population: $\mathrm{F}(170)=20.784, \mathrm{p}<0.001$; Degree of decentralization: $\mathrm{F}(170)=34.495, \mathrm{p}<0.001]$

Bold: values representing the highest heterogeneity

Data sources: Vanhanen (2009a); World Development Indicators Online Database (2010)

Tables 1 and 2 present some insights regarding the association of resource distribution with both the transition to and the consolidation of democracy between 1975 and 2007. For an easy overview, the values representing the most unequal distribution of resources or the highest heterogeneity appear in bold face in tables 1 to 3 . For all of the variables under scrutiny, established democracies exhibit the most egalitarian distribution of intellectual and economic resources as well as the lowest level of gender inequality. The gap between male and female literacy is largest in established autocracies (15 percentage points) and failed democratizers (13 percentage points), whereas in robust democratizers the gap favors males only by 4 percentage points and in established democracies, it does not exist any more.

It is striking, however, that the complementary expectation that established autocracies are characterized by the highest levels of inequality holds true for only some of the variables. Apparently, a high Gini Index, a low 
Table 2

Comparison of means: Intellectual power resource distribution and gender inequality

\begin{tabular}{llccc}
\hline & & \multicolumn{2}{c}{ Intellectual power resources } & Gender literacy \\
\cline { 3 - 4 } & & $\begin{array}{c}\text { Tertiary } \\
\text { enrollment ratio } \\
\text { gap }\end{array}$ & $\begin{array}{c}\text { Adult literacy } \\
\text { rate }(\%)\end{array}$ & \\
& & $(\%)$ & & \\
\hline Established autocracy & mean & $\mathbf{1 4 . 1 3}$ & 73.13 & $\mathbf{1 5 . 0 5}$ \\
& $\mathrm{N}$ & 47 & 47 & 43 \\
Failed democratizer & mean & 17.96 & $\mathbf{6 9 . 1 2}$ & 12.77 \\
& $\mathrm{~N}$ & 25 & 25 & 26 \\
Tenuous democratizer & mean & 14.37 & 76.80 & 10.12 \\
& $\mathrm{~N}$ & 30 & 30 & 29 \\
Robust democratizer & mean & 33.45 & 86.73 & 4.28 \\
& $\mathrm{~N}$ & 40 & 40 & 43 \\
Established democracy & mean & 54.52 & 96.41 & -0.25 \\
& $\mathrm{~N}$ & 29 & 29 & 28 \\
\hline
\end{tabular}

Oneway ANOVA reveals that there are statistically significant differences between the groups [Tertiary enrollment ratio: $\mathrm{F}(170)=27.322, \mathrm{p}<0.001$; Adult literacy rate: $\mathrm{F}(170)=9.773$, $\mathrm{p}<0.001$; Gender literacy gap: $\mathrm{F}(168)=16.849, \mathrm{p}<0.001]$

Bold: values representing the highest heterogeneity

Data sources: UNDP (2002); Vanhanen (2009a)

percentage of family farms, a high fraction of agricultural population, a low degree of decentralization, as well as a low tertiary enrollment ratio, a low adult literacy rate and a high gender literacy gap do not fundamentally impede democratic transitions, but are likely to hamper democratic consolidation and lead to failed or tenuous democratization instead. For the Vanhanen indicators of power resource distribution as well as for gender inequality, post-hoc tests ${ }^{10}$ show that the mean heterogeneity levels of established autocracies, failed democratizers and tenuous democratizers hardly differ from each other, but do significantly differ from robust democratizers and established democracies. High income inequality, as

10) Since Levene's test revealed that variances are unequal, we used the t statistic-based Tamhane T2, a test accounting for heterogeneous variances, as post-hoc testing procedure for the comparison of means in tables 1 and 2. 
measured by the Gini Index, complicates democratic consolidation, as it seems to be conducive to becoming a tenuous democratizer. This is consonant with the theoretical assumption of inequality research that income inequality might under certain conditions be the trigger of democratic transitions, but on the way almost always leads to social unrest.

Table 3 illustrates the relation between ethnic heterogeneity and democratic development. The measures of ethnic fractionalization and ethnic polarization that we chose for our analysis adopt a narrow definition of ethnicity, restricting it to racial and linguistic features. However, Alesina and his coauthors constructed three different indices measuring linguistic fractionalization, religious fractionalization and ethnic fractionalization, the last being a combination of racial and linguistic characteristics (Alesina et al. 2003: 159). The fractionalization indices reflect the probability that two randomly selected individuals do not belong to the same group; it varies between 0 and 1 (the closer to 1 , the higher the ethnic fractionalization of a country). While giving us a clue about the amount of fractionalization, the index does not tell us the exact number and size of relevant groups. In turn, Montalvo and Reynal-Querol (2005) developed a measure of ethnic polarization, assessing whether the constellation of ethnic groups in a country comes close to the equilibrium between two groups that is deemed particularly dangerous. Hence, the polarization index captures how far away the distribution of ethnic groups is from a bipolar distribution. It also varies between 0 and 1 , larger numbers signifying a stronger polarization of a society. As demonstrated by the values in table $3,{ }^{11}$ neither ethnic and language fractionalization nor ethnic polarization block democratic transitions, but both facets of ethnic heterogeneity have a damaging effect on the prospects for democratic consolidation, since the countries with the highest average fractionalization and polarization end up in the category of failed democratizers. The remarkable exception is religious fractionalization, where the highest fractionalization actually is present in established democracies, albeit no statistically significant differences between the categories exist. ${ }^{12}$

\footnotetext{
11) Faced with equal variances according to the Levene's test, we employed the commonly used Bonferroni and LSD post-hoc tests for comparison of means in table 3.

12) Examining the effect of fractionalization on the quality of government, Alesina and his coauthors found the same pattern of an exceptionally good performance of religiously
} 
Table 3

Comparison of means: Ethnic heterogeneity

\begin{tabular}{llcccc}
\hline & & \multicolumn{3}{c}{ Fractionalization } & Polarization \\
\cline { 3 - 5 } & & Ethnic & Language & Religious \\
\hline Established autocracy & mean & 0.494 & 0.431 & 0.396 & 0.507 \\
& $\mathrm{~N}$ & 45 & 43 & 46 & 30 \\
Failed democratizer & mean & $\mathbf{0 . 5 7 6}$ & $\mathbf{0 . 5 3 7}$ & 0.426 & $\mathbf{0 . 6 5 1}$ \\
& $\mathrm{N}$ & 26 & 26 & 26 & 19 \\
Tenuous democratizer & mean & 0.517 & 0.445 & 0.453 & 0.524 \\
& $\mathrm{~N}$ & 30 & 30 & 30 & 24 \\
Robust democratizer & mean & 0.400 & 0.338 & 0.450 & 0.530 \\
& $\mathrm{~N}$ & 44 & 42 & 45 & 32 \\
Established democracy & mean & 0.278 & 0.257 & $\mathbf{0 . 4 7 2}$ & 0.407 \\
& $\mathrm{~N}$ & 35 & 34 & 35 & 29 \\
\hline
\end{tabular}

Oneway ANOVA reveals that differences aren't statistically significant between all of the groups [Ethnic fractionalization: $F(179)=7.463, p<0.001$; Language fractionalization: $F(174)=4.889$, $\mathrm{p}<0.001$; Religious fractionalization: $\mathrm{F}(181)=0.623, \mathrm{p} \leq 0.646$; Ethnic polarization: $\mathrm{F}(133)=$ $3.100, \mathrm{p} \leq 0.018]$.

Bold: values representing the highest heterogeneity

Data sources: Alesina et al. (2003); Montalvo \& Reynal-Querol (2005)

Table 4 presents the results of a series of ordered probit models. This type of regression model is applicable when the outcome consists of ordered discrete possibilities. The models in table 4 assess the independent effects of each hypothesized dimension of heterogeneity, contingent on the inclusion of level of development, on the probability of becoming an established autocracy, a failed democratizer, a tenuous democratizer, a robust democratizer, or an established democracy. Hence, this model assesses the impact of heterogeneity both on democratic transition (i.e. the probability of leaving the established autocracy category) and democratic consolidation (i.e. the probability of reaching the robust democratizer or established democracy categories). High economic development is widely seen as beneficial for democracy. Higher levels of development are typically associated with larger middle classes, higher levels of education and a growing

fractionalized societies. They argue that this is because religious fractionalization tends to be higher in more tolerant and free societies (Alesina et al. 2003: 158). 
emphasis on self-expression values, and the link between economic development and democracy is considered "one of the most powerful and robust relationships in the study of comparative national development" (Diamond 1992: 110). To assess economic development, we use GDP per capita at purchasing power parity (current international US dollars), averaged over the years $2002-2007 . .^{13}$ We capture economic inequality using Vanhanen's index of economic power resources, which is a composite index including family farms, agricultural population, and estimated degree of decentralization of economic power resources. A higher value on this index denotes a more equal distribution of power resources. ${ }^{14}$

Model 1 shows that both economic development and a more equal distribution of economic power resources have a positive, statistically significant impact on democracy. In turn, as model 2 demonstrates, a high amount of gender inequality lowers the probability of democratic transition and democratic consolidation. In model 3 , the sign of ethnic fractionalization points in the expected direction, but the variable barely falls short of statistical significance. ${ }^{15}$ This corresponds to the results of the comparisons of means in table 3 where failed and tenuous democratizers actually exhibited a higher level of ethnic fractionalization than established autocracies. The implication is that ethnic fractionalization does not act as an impediment to democratic transition, but makes the process of democratic consolidation more troublesome.

In accordance with our assumption that heterogeneity is particularly problematic for democracy once cleavages become politicized, we include an additional model assessing the impact of ethnic heterogeneity that has escalated into ethnic conflict. Ethnic conflict is a dummy variable denoting that a country experienced a severe conflict (characterized by an annual fatality level of more than 1000) in more than three consecutive years between 1980 and 2006, and that this conflict had an ethnic component. ${ }^{16}$ As model 4 shows, ethnic conflict indeed exerts a statistically significant

\footnotetext{
13) Data was taken from the World Development Indicators Online Database (2010). The values were transformed to their natural logarithms.

14) See fn. 9 for the exact calculation of the index.

15) In a model including all cases for which data on ethnic fractionalization is available, the variable attains statistical significance at $\mathrm{p}<0.05$.

16) The variable was coded using the Political Instability Task Force dataset (Goldstone et al. 2010; Marshall, Gurr \& Harff 2009).
} 
Table 4

Ordered probit regressions of regime type on dimensions of heterogeneity

\begin{tabular}{l|ccccc}
\hline Variable & Model 1 & Model 2 & Model 3 & Model 4 & Model 5 \\
\hline Economic development & $0.254^{* *}$ & $0.235^{* *}$ & $0.393^{* * *}$ & $0.420^{* * *}$ & -0.020 \\
& $(0.075)$ & $(0.080)$ & $(0.074)$ & $(0.069)$ & $(0.090)$ \\
Economic power & $0.039^{* * *}$ & & & & $0.045^{* * *}$ \\
resources & $(0.006)$ & & & & $(0.006)$ \\
Gender literacy gap & & $-0.050^{* * *}$ & & $-0.058^{* * *}$ \\
& & $(0.011)$ & & & $(0.012)$ \\
Ethnic fractionalization & & & -0.585 & & \\
Ethnic conflict & & & $(0.377)$ & $-0.919^{* *}$ & $-0.949^{* *}$ \\
& & & & $0.303)$ & $(0.310)$ \\
\hline Nagelkerke's Pseudo R & 0.443 & 0.344 & 0.255 & 0.290 & 0.574 \\
\hline
\end{tabular}

Note: $\mathrm{N}=158$ countries

Coefficients express the impact of each variable on the probability of crossing the threshold to the next higher category. Standard errors in parentheses. Significance levels: ${ }^{*} \mathrm{p}<0.5 ;{ }^{* *} \mathrm{p}<0.01$; ${ }^{* * *} \mathrm{p}<0.001$

Data sources: World Development Indicators Online Database (2010); UNDP (2002); Alesina et al. (2003); Marshall, Gurr \& Harff (2009)

negative influence on democratic transition and consolidation. In fact, 14 of the 23 countries in the dataset that experienced an ethnic conflict are stable autocracies.

Model 5 looks at the three dimensions of heterogeneity - economic inequality, gender inequality and politicized ethnic heterogeneity - simultaneously. In this regression, economic development changes its sign and misses statistical significance due to high collinearity with both economic power distribution and gender literacy gap. ${ }^{17}$ However, the distribution of economic power resources, the gender literacy gap and ethnic conflict are all statistically significant and the signs are in the expected directions.

17) This confirms our suspicion uttered above (fn. 9) that those variables not only capture heterogeneity, but also reflect the level of socioeconomic development of a country. The same holds true for Vanhanen's indicators of intellectual power distribution (cf. table 2) that rendered similar results in analyses not displayed here. 
Obviously, it is debatable whether the fact that gender inequality is statistically significant allows for the conclusion that it is a cause for not achieving democracy. The same holds true for the relationship between ethnic conflict and stable autocracy. With respect to both determinants, it might be reasonable to assume that the causal link runs in the opposite direction, with stable autocracies tending to discriminate against women and more likely to be embroiled in ethnic conflict. However, our analyses also show that the bulk of autocracies affected by those problems remained autocratic over time whereas countries exhibiting less intense gender inequality, ethnic heterogeneity or ethnic conflict were able to transition to democracy.

To sum up, with respect to our hypotheses, we find that the association between interest-based cleavages and democratic transition and consolidation strongly depends on what kind of indicator is used. Income inequality, measured by the Gini Index, does not impede democratization; on the contrary, one could plausibly argue that under certain conditions high inequality in autocracies may provoke democratic transitions, for instance when the elites concede participation rights to tame redistribution claims. However, the assumption that high income inequality makes democratic consolidation more troublesome is underlined by the finding that high inequality in democratizing countries produces much more tenuous than robust democratizers. These findings strongly support Adam Przeworski's revision of modernization theory from the classical endogenous to the exogenous version (Przeworski et al. 2000).

The fact that some of the indicators of socioeconomic heterogeneity seem to reflect the level of development does not harm our results, but actually points to an additional issue that has been considered relevant by the literature on income inequality and democracy: the interdependence between inequality and level of development (Houle 2010; Mainwaring \& Pérez-Liñán 2003; Muller 1995; Reenock, Bernhard \& Sobek 2007). An unequal distribution of resources has different meanings and consequences for democracy at different levels of development. Especially in developing countries, large economic disparities allegedly threaten the stability of democracy (Arat 1991; Strasser 1999). If even in the face of economic growth the situation of the poorest sectors of society does not improve, a democratic breakdown becomes more likely. Looking once again at the tables, precisely those variables that also capture economic 
development - the bulk of Vanhanen's indicators as well as the gender literacy gap - have a clear monotonic association with democratization, meaning that the highest amount of inequality results in autocracy. This implies that those factors act as a strong impediment to democratization. In turn, the measures of interest-based heterogeneity that are not confounded with development tend to lead to failed or tenuous democratization.

We also found support for our assumption that identity-based cleavages lead to political instability and hence impede democratic consolidation. Ethnic heterogeneity does not fundamentally block democratization, but puts into question the success of democratic consolidation, as can be deduced from the fact that the highest ethnic and language fractionalization and the highest ethnic polarization is observed among failed democratizers. In divided societies - particularly in a post-conflict environment - competitive political participation often functions along ethnic (or other) divides, which might hamper democratic consolidation. But only those cases where identity-based cleavages were politicized and escalated into violent conflict register a negative effect of heterogeneity both on democratic transition and consolidation: As model 4 in table 4 demonstrates, democratization, let alone democratic consolidation, is unlikely to happen in those countries.

\section{Implications: How to Handle Heterogeneity}

Analyzing the effect of heterogeneity on democracy lies at the intersection of structural and actors' approaches to the explanation of democratic transition and democratic consolidation: It departs from the macro level and the analysis of aggregate data on a national level by looking at the distribution of economic resources and cultural traits among individuals and groups. This way, it emphasizes the potential of actors, particularly groups representing the interest of a certain faction within a heterogeneous society, to influence the course of democratization. The structural factors that we looked at in our empirical analysis turned out to be conducive or less conducive to democracy. However, as the features of heterogeneity hardly change over time, heterogeneity by itself cannot explain an escalation into conflict and is also unlikely to directly impact on a transition to democracy or democratic breakdown. Hence, future research should 
account for actors and their way to deal with the given structural conditions such as heterogeneity.

One could argue that in a situation where a necessary minimum of economic, cultural and structural requisites for democracy are given, but these factors are nevertheless not yet sufficiently advanced to guarantee a robust and sustainable democratization, actors and their political strategies, alliances and decisions are particularly relevant and can compensate for the gap between necessary and sufficient structural conditions (Merkel 2010: 84). However, actors could as well act as spoilers and undermine an ongoing democratization process when they decide to emphasize, reinforce, instrumentalize and politicize heterogeneity. Therefore, we have to ask which institutions, procedures or actors can be used to accommodate heterogeneity in order to prevent it from becoming politicized and block the path towards democracy or challenge a peaceful democracy.

A concept frequently advanced in this context is inclusion. In a wider sense, the term "inclusion" means the legal, political, economic, social, and cultural integration of all citizens or even the whole population that lives in the defined territory of a state. Modern Western societies and polities describe themselves as democracies which are committed to the values of freedom, tolerance, justice, equal opportunities, free development of the individual, welfare, and sometimes even the pursuit of happiness. A narrower definition related to the political structure of democratic regimes relates only to the legal and political norms of the constitution, to its procedures and political institutions. According to this narrower definition, these structures should provide the institutional guarantee that neither legal nor political discrimination (or exclusion) can take place.

The standard approach how to counter socioeconomic inequalities and hence to calm interest-based cleavages is redistribution (Acemoglu \& Robinson 2006; Boix 2003; Houle 2009). Inequality potentially has two contradictory effects for democracy that are both linked to redistribution: High economic inequality makes democracy more costly for the elites due to the increased demands for redistribution but, at the same time, it increases the potential gains from redistribution for the population. Hence, both in democratizing states and existing democracies characterized by high inequality, redistribution is one strategy to prevent the severe socioeconomic imbalances from turning into protest and revolution. An alternative strategy is development: An improvement of the average living 
conditions, such as access to food, housing, health and education may well cater to the needs of the most disadvantaged sectors of the population and lead to a reduction of poverty, while leaving the overall inequality untouched.

The literature advances several ways for democracies to deal with identity claims and political demands of ethnic minorities (Bellamy 2000; Offe 2003), which include cultural and linguistic assimilation, granting and implementing equal rights, granting special group rights to ethnic minorities or initiating and extending the devolution of governmental powers. Jack Snyder (2008), explicitly referring not only to established democracies, but focusing on transitional countries, arrays the policies to manage ethnically divided democratizing societies along two intersecting axes, depending on whether the solution separates or integrates the groups and whether it would appease or repress their demands. Repressive solutions like coercive assimilation, an ethnic "control" regime or the expulsion of minorities are not viable in democracies. Appeasing solutions include integration by granting equal rights, multiculturalism, realized by granting special group rights to minorities, and ethnofederalism or autonomy.

In immigrant societies, integration was traditionally achieved by assimilation. The new citizens should assimilate themselves into the cultural mainstream (Leitkultur) of the community. It is expected, if not required, that the immigrants adopt the language of their new society and that their religious beliefs should be compatible with already existing constitutional and cultural norms. Samuel Huntington (2004) argues that the USA worked as a melting pot only as long as the immigrants took over English as their main language and accepted the basic cultural norms of the American "way of life". The successful melting pot model ended when Hispanics kept their native language, clustered regionally in parts of Florida, Texas, or California and maintained their own cultural way of life. However, integration through assimilation of immigrants and autochthonous minorities becomes less attractive among constitutionalists and the democratic theorists of today. It may well have been the practice of dictators like Franco, Milosevic, or Tudjman, and, in a milder form, of post-Soviet governments in Latvia and Estonia, but it appears to be incompatible with the basic norms of democracy. Therefore, liberal philosophers and constitutionalists insist that in democracies integration basically implies that all citizens have equal rights and duties. Within this framework, everybody 
has the equal right and chance to promote his or her views and cultural identity as long as they do not interfere with the right of others to act likewise, regardless which ethnos, culture, or religion he or she adheres to. Religion and culture is relegated to the private sphere. John Rawls (1971) argues that only such a "neutral constitution" would secure an "overlapping consensus", internal peace, and justice, because it places the constitution beyond "the fact of pluralism". Such a consensus is based on what Rawls calls the "method of avoidance": people abstract from their substantive conceptions of ethnicity, religion, and the common good in order to facilitate cooperation and political coexistence.

Advocates and representatives of ethnic, linguistic, and religious minorities oppose this liberal point of view. They argue that formal equal rights are not sufficient for "structurally disadvantaged minorities" to exercise these same rights as the majority can. They need additional group rights in order to preserve their identity and have the same opportunities as the majority. Only when the constraints that minorities are not responsible for are removed, they can achieve the same degree of freedom and equality the majority already enjoys. However, the full removal of constraints means that the minority groups need additional rights. Will Kymlicka (1995) identifies three different kinds of group rights: polyethnic rights, special representation rights, and self-government rights:

- Polyethnic rights give either specified exemption from specific laws and duties which disadvantage minorities or grant additional rights to them. For example, Sikhs are freed from wearing helmets on motor-bikes and Muslim women are allowed to wear the veil at the workplace. Additional cultural rights are provided for the teaching of minority languages and religions.

- Special representation rights try to secure parliamentary representation for certain minorities by reserving special seats to them in the legislature, tailor the PR-electoral system, or by supporting quotas in parties and interest groups. These special representation rights are sometimes given to linguistic and more rarely to religious minorities. This approach is congruent with what Lijphart $(1991,2004)$ calls "consociational democracy".

- Self-government rights are reserved for those minorities who live in a highly concentrated region of the state territory. Federalizing the 
country and/or devolving specific jurisdiction to regional self-governments, such as education or health, is often seen as the best way to protect the minority from being culturally overwhelmed or absorbed by the majority.

To promote cultural identity without taking the necessity of socio-political cohesion of the society into account can lead to deeply entrenched cleavages, secession or even civil wars, especially if identity-based cleavages coincide with socioeconomic imbalances. Therefore, democratic regimes have to balance claims for cultural diversity with the necessary amount of common identity and belongingness of a political community. Unfortunately, it is impossible to decide in abstracto whether the implementation of equal individual rights, group rights or territorial devolution is the best solution. Future research should therefore examine the effects of these devices in a comparative setting. ${ }^{18}$ Anyhow, equal individual rights are the conditio sine qua non for each constitutional democracy. They are necessary, but they are obviously not sufficient in modern heterogeneous societies anymore. Even the full implementation of social rights will not evaporate the ethno-cultural claims. They may be criticized as primordial and disruptive, but if significant portions of the population ask for them, democracy has to deal with these demands. The same holds true for countries undergoing democratic transition.

As long as the ideal Rawlsian world of equal individual rights and justice does not automatically lead to a fair distribution of both economic and cultural goods, legal equality has to be complemented by special rights which allows the structurally or culturally disadvantaged to be treated as equals. Accordingly, Snyder (2008) advocates a sequencing of strategies in democratizing societies. In the wake of a civil war, for instance, short-term stabilization might be achieved by a power-sharing accord that ensures each of the belligerent groups a share of bureaucratic posts, legislative seats and local administrative control. However, as the locking up of group politics in power-sharing arrangements hinders long-term integration, these strategies should be abolished in the long run and replaced by more integrative, civic solutions. The constant redefinition and renegotiation of

18) For a first quantitative study assessing the consequences of power sharing and power dividing for ethnonational crises and armed conflicts, see Roeder (2005). 
inter-group relations may be the price democracies have to pay if they actually want to reconcile liberty and diversity in heterogeneous societies. Hence the already existing norms, procedures, and institutions have to be adapted in an ever-changing process to meet the specific demands of all citizens in order to promote freedom and equality. In a world of increasing economic, religious, and ethnic diversity this has become a crucial issue which determines the stability and quality of young as well as mature democracies.

\section{Literature}

Acemoglu, Daron \& Robinson, James A. 2006: Economic Origins of Dictatorship and Democracy. Cambridge: Cambridge University Press.

Adcock, Robert \& Collier, David 2001: "Measurement Validity: A Shared Standard for Qualitative and Quantitative Research.” American Political Science Review 95 (3), 529-546.

Alesina, Alberto, et al. 2003: "Fractionalization." Journal of Economic Growth 8 (2), $155-194$.

Arat, Zehra F. 1991: Democracy and Human Rights in Developing Countries. Boulder/ London: Lynne Rienner.

Bell, Daniel 2000 (1960): The End of Ideology: On the Exhaustion of Political Ideas in the Fifties. Cambridge: Harvard University Press.

Bellamy, Richard 2000: Rethinking Liberalism. London/New York: Pinter.

Boix, Carles 2003: Democracy and Redistribution. New York: Cambridge University Press.

Bollen, Kenneth A. \& Jackman, Robert W. 1985: "Political Democracy and the Size Distribution of Income." American Sociological Review 50, 438-457.

— 1995: "Income Inequality and Democratization Revisited: Comment on Muller." American Sociological Review 60, 983-989.

Brass, Paul R. 1991: Ethnicity and Nationalism. Theory and Comparison. New Delhi et al.: Sage.

Burkhart, Ross E. 1997: "Comparative Democracy and Income Distribution: Shape and Direction of the Causal Arrow." Journal of Politics 59 (1), 148-164.

_ 2007: "Democracy, capitalism, and income inequality: Seeking causal directions." Comparative Sociology 6 (4), 481-507.

Clague, Christopher, Gleason, Suzanne \& Knack, Stephen 2001: "Determinants of Lasting Democracy in Poor Countries: Culture, Development, and Institutions." Annals of the American Academy of Political and Social Science (573), 16-41.

Crouch, Colin 2004: Post-democracy. Cambridge: Polity Press.

Dahl, Robert A. 1971: Polyarchy. Participation and Opposition. New Haven/London: Yale University Press. 
1989: Democracy and its Critics. New Haven/London: Yale University Press.

2006: On Political Equality. New Haven: Yale University Press.

Diamond, Larry 1992: “Economic Development and Democracy Reconsidered”, in: Marks, Gary \& Diamond, Larry (ed.): Reexamining Democracy. London/Newbury Park: Sage, 93-139.

Donno, Daniela \& Russett, Bruce 2004: "Islam, Authoritarianism, and Female Empowerment. What Are the Linkages?" World Politics 56 (4), 582-607.

Easton, David 1965: A Systems Analysis of Political Life. New York et al.: Wiley.

Feng, Yi 2003: Democracy, Governance, and Economic Performance. Theory and Evidence. Cambridge, MA: MIT Press.

Fish, M. Steven \& Wittenberg, Jason 2009: “Failed Democratization”, in: Haerpfer, Christian W. et al. (ed.): Democratization. New York/Oxford: Oxford University Press, 249-265.

Fish, Steven 2002: "Islam and Authoritarianism." World Politics 55 (1), 4-37.

Fish, Steven \& Brooks, Robin S. 2004: "Does Diversity hurt Democracy?” Journal of Democracy 15 (1), 154-166.

Goldstone, Jack A., et al. 2010: "A Global Model for Forecasting Political Instability." American Journal of Political Science 54 (1), 190-208.

Habermas, Jürgen 1989 (1962): The Structural Transformation of the Public Sphere: An Inquiry into a Category of Bougeois Society. Cambridge: Polity Press.

Hillmann, Karl-Heinz 1994: Wörterbuch der Soziologie. Fourth revised and updated edition, Stuttgart: Kröner.

Horowitz, Donald L. 1985: Ethnic Groups in Conflict. Berkeley: University of California Press.

_ 2008: "Conciliatory Institutions and Constitutional Processes in Post-Conflict States." William and Mary Law Review 49 (4), 1213-1248.

Houle, Christian 2009: "Inequality and Democracy. Why Inequality Harms Consolidation but Does Not Affect Democratization.” World Politics 61 (4), 589-622.

2010: Inequality, Economic Development and Democratization. Unpublished manuscript, Rochester, NY: University of Rochester.

Huntington, Samuel P. 1968: Political Order in Changing Societies. New Haven/London: Yale University Press.

— 1971: "The Change to Change. Modernization, Development, and Politics." Comparative Politics 3 (3), 283-322.

1993: "The Clash of Civilizations?" Foreign Affairs 72 (3), 22-49.

2004: Who Are We? The Challenges to America's National Identity. New York et al.: Simon \& Schuster.

Inglehart, Ronald, Norris, Pippa \& Welzel, Christian 2002: "Gender Equality and Democracy." Comparative Sociology 1 (3-4), 321-345.

Karl, Terry Lynn 2000: "Economic Inequality and Democratic Instability." Journal of Democracy 11 (1), 149-156.

Kreuzer, Peter \& Weiberg, Mirjam 2007: Zwischen Bürgerkrieg und friedlicher Koexistenz. Interethnische Konfliktbearbeitung in den Philippinen, Sri Lanka und Malaysia. Bielefeld: Transcript. 
Kuznets, Simon 1955: "Economic Growth and Income Inequality." American Economic Review 45 (1), 1-28.

Kymlicka, Will 1995: Multicultural Citizenship. A Liberal Theory of Minority Rights. Oxford: Oxford University Press.

Lane, Jan-Erik \& Ersson, Svante 2002: Culture and Politics. A comparative approach. Aldershot: Ashgate.

- 2003: Democracy. A comparative approach. London: Routledge.

Lenski, Gerhard 1966: Power and Privilege: A Theory of Social Stratification. New York: McGraw-Hill.

Lenski, Gerhard, Nolan, Patrick \& Lenski, Jean 1995: Human Societies. An Introduction to Macrosociology. Seventh edition, New York: McGraw-Hill.

Lerner, Daniel 1958: The Passing of Traditional Society. Glencoe: The Free Press.

Lijphart, Arend 1991: "The Power-Sharing Approach", in: Montville, Joseph V. (ed.): Confict and Peacemaking in Multiethnic Societies. New York: Lexington Books, 491-510.

1999: Patterns of Democracy. Government Forms and Performance in Thirty-Six Countries. New Haven/London: Yale University Press.

_ 2004: "Constitutional Design for Divided Societies." Journal of Democracy 15 (2), 96-109.

Lipset, Seymour Martin 1959: "Some Social Requisites of Democracy: Economic Development and Political Legitimacy." American Political Science Review 53, 69-105.

Mainwaring, Scott \& Pérez-Liñán, Aníbal 2003: "Level of Development and Democracy. Latin American Exceptionalism, 1945-1996." Comparative Political Studies 36 (9), 1031-1067.

Marshall, Monty G., Gurr, Ted Robert \& Harff, Barbara 2009: Political Instability Task Force Problem Set: Internal Wars and Failures of Governance, 1955 - Most Current Year. Codebook, Center for Global Policy.

Marshall, Thomas H. 1992: "Citizenship and Social Class", in: Marshall, Thomas H. \& Bottomore, Tom (ed.): Citizenship and Social Class. London: Pluto Press, 3-51.

Merkel, Wolfgang 2010: Systemtransformation. Eine Einführung in die Theorie und Empirie der Transformationsforschung. 2. überarbeitete und erweiterte Aufl., Wiesbaden: VS Verlag für Sozialwissenschaften.

Meyer, Thomas 2005: Theorie der sozialen Demokratie. Wiesbaden: VS Verlag für Sozialwissenschaften.

Midlarsky, Manus I. \& Midlarsky, Elizabeth 1997: "Environmental influences on democracy: aridity, warfare, and land inequality”, in: Midlarsky, Manus I. (ed.): Inequality, Democracy and Economic Development. Cambridge: Cambridge University Press, 45-79.

Mill, John Stuart 1861: Considerations on Representative Government. London: Parker.

Montalvo, José G. \& Reynal-Querol, Marta 2005: "Ethnic Polarization, Potential Conflict, and Civil Wars." American Economic Review 95 (3), 796-816.

Muller, Edward N. 1988: "Democracy, Economic Development, and Income Inequality." American Sociological Review 53, 50-68.

1995: "Economic Determinants of Democracy." American Sociological Review 60, 966-982. 
O’Donnell, Guillermo 1993: "On the State, Democratization and Some Conceptual Problems: A Latin American View with Glances at Some Postcommunist Countries." World Development 21 (8), 1355-1369.

O’Donnell, Guillermo 1998: "Horizontal Accountability in New Democracies." Journal of Democracy 9 (3), 112-126.

Offe, Claus 2003: “'Homogeneity' and Constitutional Democracy. Coping with Identity Conflicts through Group Rights”, in: Offe, Claus: Herausforderungen der Demokratie. Zur Integrations- und Leistungsfähigkeit politischer Institutionen. Frankfurt: Campus, 151-181.

Parsons, Talcott 1964: "Evolutionary Universals in Society." American Sociological Review 29, 339-357.

— 1971: The System of Modern Societies. Englewood Cliffs: Prentice Hall.

Paxton, Pamela 2009: "Gender and Democratization", in: Haerpfer, Christian W. et al. (ed.): Democratization. New York/Oxford: Oxford University Press, 145-157.

Przeworski, Adam, et al. 1996: "What Makes Democracies Endure?” Journal of Democracy 7 (1), 39-55.

2000: Democracy and Development. Political Institutions and Well-Being in the World, 1950-1990. Cambridge: Cambridge University Press.

Putnam, Robert D. 1993: Making Democracy Work. Civic Traditions in Modern Italy. Princeton: Princeton University Press.

1995: “Bowling Alone: America's Declining Social Capital." Journal of Democracy 6 (1), 65-78.

Rabushka, Alvin \& Shepsle, Kenneth A. 1972: Politics in Plural Societies. A Theory of Democratic Instability. Columbus, $\mathrm{OH}$ : Merrill.

Rawls, John 1971: A Theory of Justice. Cambridge, MA: Belknap Press.

Reenock, Christopher, Bernhard, Michael \& Sobek, David 2007: "Regressive Socioeconomic Distribution and Democratic Survival.” International Studies Quarterly 51 (3), 677-699.

Reinhold, Gerd, Lamnek, Siegfried \& Recker, Helga (ed.) 2000: Soziologie-Lexikon. München: Oldenbourg.

Roeder, Philip G. 2005: "Power Dividing as an Alternative to Ethnic Power Sharing", in: Roeder, Philip G. (ed.): Sustainable Peace. Power and Democracy after Civil Wars. Ithaca: Cornell University Press, 51-82.

Schneckener, Ulrich 2002: "Making Power-sharing Work: Lessons from Successes and Failures in Ethnic Conflict Regulation." Journal of Peace Research 39 (2), 203-228.

Snyder, Jack 2008: "Problems of Democratic Transition in Divided Societies", in: Nardulli, Peter F. (ed.): Domestic Perspectives on Contemporary Democracy. Urbana/Chicago: University of Illinois Press, 11-32.

Stepan, Alfred \& Robertson, Graeme B. 2003: “An 'Arab' more than 'Muslim' electoral gap." Journal of Democracy 14 (3), 30-44.

Strasser, Carlos 1999: Democracia \& desigualdad: sobre la "democracia real" a fines del siglo $X X$. Buenos Aires: Consejo Latinoamericano de Ciencias Sociales CLACSO.

Teorell, Jan \& Hadenius, Axel 2007: "Determinants of Democratization: Taking Stock of the Large-N Evidence", in: Berg-Schlosser, Dirk (ed.): Democratization. The State of the Art. Opladen/Farmington Hills: Barbara Budrich, 69-95. 
Tilly, Charles 2000: "Processes and Mechanisms of Democratization." Sociological Theory 18 (1), 1-16.

Tilly, Charles 2007: Democracy. Cambridge: Cambridge University Press.

UNDP 2002: Human Development Report 2002: Deepening Democracy in a Fragmented World. New York: Oxford University Press.

Vanhanen, Tatu 1997: Prospects of Democracy. A study of 172 countries. London: Routledge. 2003: Democratization: A comparative analysis of 170 countries. London: Routledge. 2009a: Index of Power Resources (IPR) 2007 Tampere, Finnish Social Science Data Archive.

2009b: The Limits of Democratization: Climate, Intelligence, and Resource Distribution. Augusta, GA: Washington Summit Publishers.

Varshney, Ashutosh 2001: "Ethnic Conflict and Civil Society. India and Beyond." World Politics 53, 362-398.

Weiffen, Brigitte 2004: "The Cultural-Economic Syndrome: Impediments to Democracy in the Middle East." Comparative Sociology 3 (3-4), 353-375.

2009: Entstehungsbedingungen von Demokratien. Interne und externe Einflüsse im Vergleich. Baden-Baden: Nomos. 